\title{
Teaching Concept of College English Reading and Writing Under the Background of Ideological and Political Course
}

\author{
Hongchun Zhao
}

Shihezi University, Shihezi 832000, Xinjiang, China.

\begin{abstract}
The national conference for college ideological and political work emphasizes that we should make good use of the main channel of classroom teaching, and that all kinds of courses should go with ideological and political theory courses in the same direction to form a synergistic effect. As a basic course in colleges and universities, college English will play an irreplaceable role in the process of "all staff, whole process and all-round education". By analyzing the significance of ideological and political education in college English course, this paper puts forward the idea of integrating ideological and political education into college English teaching. In order to realize the "ideology and politics course" in college English teaching, we should rely on the course of ideological and political education.
\end{abstract}

Keywords: Ideological and Political Courses; College English Teaching; Teaching Philosophy

\section{Introduction}

In December 2016, the national conference on ideological and political work in colleges and universities proposed that "we should adhere to moral education as the central link" and "all kinds of courses should go with ideological and political theory courses in the same direction to form a synergistic effect". This important speech opened the nationwide "ideological and political course" construction. In 2019, the ideological and political theory teachers' forum again arranged and deployed to enhance the effectiveness of ideological and political education in colleges and universities. It is pointed out that "the reform and innovation of ideological and political theory course should adhere to the unity of explicit education and implicit education, tap the ideological and political education resources contained in other courses and teaching methods, so as to realize the whole process and all-round education of the whole staff". Under the background of "ideological and political course", college English teaching circles have begun to explore how to combine college English with ideological and political education. The research results mainly focus on teachers, teaching materials and teaching methods. The deep integration of ideological and political education and foreign language teaching is an important aspect of the whole process and all-round education pattern.

\section{The significance of ideological and political reform in college English course}

First of all, the infiltration of Ideological and political courses into the process of college English teaching can effectively enhance the ideological depth of contemporary college education practice and research for English teaching, innovate the teaching methods of college English, and deepen the ideological and political teaching of English course, in order to serve the national "great ideological and political" pattern. In addition, college English "ideological and political course" teaching can organically combine college English teaching and ideological and political education, which not only endows the traditional ideological and political education with fresh vitality, but also enriches the ideological and political connotation of college English course self, expanding college English course. In terms of knowledge, thought and skills, moral education is conducive

Copyright $(2020$ Hongchun Zhao

doi: 10.18686/ahe.v4i10.2951

This is an open-access article distributed under the terms of the Creative Commons Attribution Non-Commercial License (http://creativecommons. org/licenses/by-nc/4.0/), which permits unrestricted non-commercial use, distribution, and reproduction in any medium, provided the original work is properly cited. 
to the cultivation of talents needed for the construction of socialism with Chinese characteristics in the new era.

Secondly, college English is a subject with both humanity and instrumentality. As a language and culture course, English course has a variety of contents, including the current situation of the country, political system, mode of thinking, money concept, career planning, social customs, learning life and so on. Therefore, through the introduction of " ideological and political course" elements, it is necessary to excavate the ideological and political education resources, give full play to the advantages of college English curriculum, in order to improve students' cultural identity and self-confidence, enhance patriotism, and realize the unity of value rationality and instrumental rationality for college English.

Thirdly, to meet the needs of college students in English learning, ideological improvement and psychological expression enable them to keep the socialist core values in mind and practice, and cultivate their national pride, so as to enhance the effect of moral education.

\section{College English teaching concept under ideology and politics course}

Ideological and political course is not to change the original attribute of professional courses, nor to transform professional courses into ideological and political courses or to treat all courses as ideological and political courses. Instead, it is necessary to give full play to the moral education function of the course, use the discipline thinking of moral education to refine the cultural genes and value paradigm contained in the professional courses, and transform them into the concrete and vivid socialist core values. The effective teaching carrier integrates the spiritual guidance of ideal and belief into the knowledge learning in "silent education".

\subsection{Taking textbooks as carrier}

As for the content of English teaching materials, it should have a relatively perfect knowledge structure. The contents of English teaching materials should be consistent, scientific and diversified, so as to provide students with multi-dimensional education and teaching contents in the actual teaching process. In the process of setting up college English course, it is not only limited to a single English knowledge structure, but also has great linkage with other subject knowledge systems. In the process of course system construction, we should fully tap the value of the discipline itself, such as humanistic thought and moral quality value, so that students can form a kind of ideological macro-control in the actual learning process and greatly stimulate students' passion for self-learning. It enables students to interpret English knowledge and English culture at different levels, so as to enhance the standard value of course teaching.

\subsection{The study and improvement of teachers' own ideological knowledge}

Teachers are the engineers of human soul and bear the sacred mission. The preacher himself must first be clear about the word and believe in it. College teachers should insist that educators should be educated first, strive to become the disseminator of advanced ideology and culture and the firm supporter of the Party's ruling, so as to better take the responsibility of the guidance and lead the healthy growth for students. The implementation of ideology and politics course depends on teachers. The first thing to test is teachers' moral education consciousness and ability, which test teachers' personality cultivation. Teachers must adhere to the correct political guidance, strong politics, deep feelings, new thinking, wide vision and correct personality. It is necessary to adhere to the unity of teaching and education, the unity of speech and teaching by example, the unity of asking questions and paying attention to the society, the unity of academic freedom and academic norms, making classroom become the main front to carry forward the main melody and spread positive energy,

\subsection{Innovating teaching methods}

College English reading and writing course is compiled according to the unit theme. By finding the right fit point, with the help of these authentic language and profound English articles and problem-oriented basis, the course can not only ensure the scientifical and ideological content, but also break the serious and abstract teaching style of speaking and fully mobilize the students' enthusiasm to achieve the seamless connection between ideological and political knowledge and teaching content, in order to achieve the goal of education in the whole process imperceptibly. Rich ideological and political elements of language should be integrated into all teaching activities and teaching links. Single teaching methods and paths are difficult to meet such new requirements. We must integrate the advantages and strengths of different paths and teach students in accordance with their aptitude. The main role of students should be brought into full play in teaching, and they can participate in all aspects 
of teaching, which is embodied in the training process of listening, speaking, reading, writing and translation of college English. The teaching of each link can be integrated into ideological and political education, stimulate students' interest in college English learning and improve their enthusiasm for learning English. In the teaching process, we can give full play to the students' subjectivity in the classroom, such as through keynote speeches (about Chinese and western politics, economy, culture, history and other topics), group discussion, etc., so that students can fully participate in the classroom. And this behavior is praised, graded, and included in the evaluation of students, in order to stimulate students' learning motivation with corresponding learning behavior.

\section{The teaching content is more important in Ideological and political teaching}

The ideological and political teaching of college English course should be content-based, which is conducive to arousing the interest of English learners and improving their English ability. Therefore, in the course of ideological and political reform, to make it effectively integrated into teaching, we must not separate from the basic teaching content, which will affect the nature of the course and teaching progress. In addition to preparing the explanation of language skills and knowledge points of relevant units, we also need to dig deeply into the course and actively look for the elements of ideological and political education. Teachers should make rational use of the existing teaching materials. According to the learning objectives and contents of each unit, teachers can reasonably design teaching and appropriately input the corresponding ideological and political content. Teachers should not only focus on the teaching of language knowledge, but also try to dig out the political education elements that may be contained in the teaching materials. From classroom introduction, classroom explanation, sublimation theme, classroom discussion to after-school tasks, teachers need to carefully design, make full use of the advantages of network and multimedia, and with various forms such as pictures, audio and video etc., to display the differences between China and the West in culture, world outlook or values, so as to lead to students' contemplation and dialectic view of western culture, taking the essence and discard the dross and gradually to Imperceptibly realize the ideological and political education. At the same time, in the process of English teaching, teachers should pay attention to the creation of communication links, set aside a part of time according to the actual teaching situation, and seize the hot news of current events, responding to the concerns of students, in order to guide them to express their opinions in English, seize the opportunity, and timely carry out ideological and political education. It helps students form the habit of paying attention to social current events and establishes correct ideological guidance. During the discussion between teachers and students, teachers can objectively introduce various manifestations of China's strong national strength in English, such as the achievements and advantages of China in various aspects after the reform and opening up, so as to enhance students' national pride and self-confidence in values, and truly achieve the integration of language learning and ideological guidance.

\section{Conclusion}

Closely following the pace of "ideological and political course", we should combine college English teaching with ideological and political education, give full play to the role of college English course in educating people and morality, realize the same direction of college English course and ideological and political course, and form a synergistic effect. This will effectively enhance the ideological depth of college English teaching, innovate the teaching methods of college English, and enrich the ideological and political connotation of college English course itself, as well as expand the functions of college English course in knowledge, thought and skills. When imparting knowledge, we should cultivate morality and cultivate people, and deepen ideological and political teaching of English course, which is conducive to cultivating the talents with the needs of socialist construction with Chinese characteristics in the new era, in order to serve the national "great ideological and political" pattern.

\section{References}

1. Department of Higher Education, Ministry of education. Requirements for college English teaching. Beijing: Higher Education Press; 2017.

2. Yan T. Exploration of ideological and political practice in college English course - A case study of new horizon college English. Heihe Journal 2019; (05): 105-108.

3. Li Y. On the feasibility of college English classroom becoming the front of ideological and political education in colleges and universities. Education and Teaching Forum 2019; (28): 28-29. 